\title{
Does Ownership Structure Affect the Motivation of Compensation Contract of Earnings Management? -From China's Data
}

\author{
Jing Long, Yanxi Li, Xiuwen Xu, Linlin Fu
}

School of Management \& Economics, Dalian University of Technology, Dalian, China.

Email: longj@mail.dlut.edu.cn,mrliyx@dlut.edu.cn, \{xxw133,franfulinlin\}@,hotmail.com

Received July $10^{\text {th }}, 2011$; revised August $16^{\text {th }}, 2011$; accepted August $25^{\text {th }}, 2011$.

\begin{abstract}
This paper is to explore that if ownership structure exactly affects on earnings management, especially on how to constrain executive compensation motivation to earnings management in the emerging market of China. We use five variables to quantify various corporate governance mechanisms including ownership structure and executive compensation for 1024 listed firms sample within two years. We find that earnings management is positively affected by executive compensation motivation, while this influence is constrained mostly by ownership concentration. This finding reflects the current situation for the weak corporate governance in the emerging market of China. Therefore, such a significant relationship is useful to control level of earnings management and improve the China's emerging market developing healthily, stably and harmoniously.
\end{abstract}

Keywords: Ownership Concentration, Executive Compensation, Earnings Management, Corporate Governance

\section{Introduction}

Over three hundred years ago, Adam Smith raised the issue of the separation of ownership and stewardship in joint-stock corporations in his masterwork "The Wealth of Nations". It was therefore suggested that a set of effective mechanisms should be in place to resolve the conflict of interests between firm owners and managers. The early 2000 s were the years in which a numbers of high-profile corporate financial frauds took place, including large companies such as Enron, WorldCom, Tyco, Global Crossing and others [1]. To respond to these corporate financial frauds, the US Congress enacted the Sarbanes-Oxley (SOX) Act in 2002 and introduced a new era of corporate governance, including requirements for auditor independence, independence of a firm's audit committee, the responsibility of a firm's $\mathrm{CEO}$ and $\mathrm{CFO}$ on financial reports, and the protections on whistleblowers. Since the occurrence of financial frauds and the enactment of SOX in early 2000s, corporate governance has become a crucial mechanism for government regulations on both corporate and capital market operations.

Berle and Means [2] believed that when cooperate shares are widely spread over to a great number of small shareholders, there is a good separation between the ownership and the power of operational management, in which the managers act as the agents for the shareholders. However, Fama [3], and Jensen and Meckling [4] argued that when the managers do not own a great number of shares, they may pursue personal interest at the expense of the interest of shareholders while making managerial decisions. Therefore, the business in a form of corporation exists with interest conflicts between owners and managers, which is referred as traditional agency theory or equity agency problem. Moreover, this equity agency problem would become a central agency problem, in which new conflicts arise between controlling and noncontrolling shareholders when mangers also own significant amount of shares through stock options, pyramidal ownership structure, or crossing holdings $[5,6]$.

Healy [7] has empirically researched on bonus plan and earnings management. He found that the managers would choose the correspondingly policies and process to lower the report earnings if the bonus plan proposed the minimum and maximum process to lower the report earnings. While the managers would choose the opposite policies to increase the report earnings, as there is no limitation on bonus plan. 
Watts and Zimmerman [8] found that corporate governance attributes help investors by aligning the interests of managers with the interests of shareholders and also by enhancing the reliability of financial information and the integrity of reporting process. It confirmed that the mechanism of corporate governance helps restrict mangers in the behavior of earnings management.

The purpose of this paper is to explore the mechanisms of corporate governance used by listed firms in the Chinese emerging capital market, and the effect of governance and ownership on earnings management, especially on how to constrain executive compensation's motivation to earnings management. The results of this research will help users better analyze and understand the financial statements prepared by the Chinese listed firms. In addition, our results will also help regulators and policy makers in policy making, enactment of regulations/laws and their enforcement.

In addition of this section of Introduction, the remainder of this paper is organized into six more sections. Section 2 presents research framework and hypothesis. Section 3 discusses the methodology used in this research. Section 4 presents data, descriptive statistics and the research results. Section 5 provides the sensitivity test and section 6 proposes conclusion and suggestion.

\section{Research Framework and Hypothesis}

Dennis and McConnell [9] defines corporate governance as " $\cdots$ the set of mechanisms that maintain an appropriate balance between the rights of shareholders $\cdots$ and the needs of the board and management to direct and manage the corporation's affairs." The corporate governance mechanisms may help resolve the two sets of conflicts: between owners and managers, and between controlling shareholders and minority shareholders. It consist ownership structure, board of directors, executive compensations, financial disclosure, etc. In this paper, we consider and assess ownership structure (e.g. concentration ownership), board of directors (e.g. board size, proportion of independent directors, the duality of CEO), and the managers (e.g. the top3 executive compensations), which effect on earnings management.

\subsection{Executive Compensation}

We define the top managers as CEO, the chairperson of the board of directors or supervisors, and the general manager of a firm. Watts and Zimmerman [8] stated that managers have incentives to advance the earnings from the future to the current accounting period when a bonus award plan exists. In their later studies, Dechow and Sloan [10] consistently confirmed that managers would use accounting judgments to increase earnings-based bo- nus awards. We define sata- 3 is the annual salaries of the 3 top managers. The following hypothesis flows from the literature discussed as:

Hypotheses 1: The executive compensation (sala_3) has a negative impact on earnings management.

\subsection{Ownership Structure}

It is believed that one of the most important ways through which a firm maximizes its value is through well-designed ownership structure of the firm's shares. Concentrated equity ownership can be bad for the governance of the firm since it gives the largest shareholders too much discretionary powers of using firm resources in ways that serve their own interest at the expense of other shareholders. That is, too much concentrated ownership (the largest shareholders) may accentuate the earnings management we mentioned earlier.

We investigate the related issue of how ownership concentration affects earnings management, a topic which has received a significant impact by the corporate governance literature on the Chinese market. We define that h10 is the ownership concentration variable represented by the sum of the square of shares held by the ten largest shareholders. Herfindahl is included to examine if the power sharing among the largest shareholders was a better mechanism of corporate governance rather than one shareholder. Thus, hypothesis 2 is developed as follows:

Hypotheses 2: The ownership concentration (h10) has a negative impact on earnings management.

Long, $\mathrm{Li}$ and $\mathrm{Fu}[11]$ suggested to use a cross item to test the constrain of ownership structure. Then we use sala_t $3 \times \mathrm{h} 10$ as a multiplication cross item between executive compensation and ownership concentration to test if compensation plan can be constrained by ownership structure for the level of earnings management.

Based upon the aforementioned theory and studies, we formulate hypothesis 3 as:

Hypotheses 3: The multiplication cross item between executive compensation and ownership concentration (sala_t3 $\times$ h10) has an impact on constraining motivation of compensation plan to earnings management.

\subsection{Board of Directors}

\subsubsection{Board Size}

Beasley [12], Dechow [13] found that, the more numbers of the board, the less ineffective supervision to the managers, and the more possible to do earnings management. Bai et al. [14] suggested board size have a positive effect on earnings management. We define $\mathrm{n}_{-} \mathrm{d}$ as the number of the board.

Hypotheses 4: When the number of the board ( $\left.n \_d\right)$ is larger, there is a lower level of earnings management. 


\subsubsection{Proportion of Independent Directors}

Dechow [13] corroborated that when there is a higher proportion of independent directors, there is lower level of earnings management. We define the proportion of independent directors as id. Thus, we develop hypothesis 5 as:

Hypotheses 5: When the proportion of independent directors (id) is higher in a firm, there is a lower level of earnings management.

\subsubsection{CEO Duality}

Fama and Jensen (1983) assert that when the CEO duality exists I a firm, the monitoring function of the board will be weaker, that would also likely lead to more earnings management. We define CEO Duality as dua. Thus, hypothesis 6 is developed as follows:

Hypotheses 6: The CEO duality (dua) has a positive impact on earnings management.

\section{Methodology of the Research}

Earnings management has also been rampant in the emerging market of China. China Securities Regulatory Commission (CSRC) requires listed companies to meet certain return on equity (ROE) criteria before they can apply for permission to issue additional shares to existing shareholders; the most important criterion for delisting a listed company is a reported net loss for three consecutive years. Whenever a contract or regulation is based on accounting numbers, managers have an incentive to manipulate those numbers to serve their own or the firm's interests. We try to illuminate how controlling shareholder and the board affect the level of earnings management.

In order to examine the relationships among ownership concentration, the board of directors, and earnings management, we first establish the following regression equation:

$$
\begin{aligned}
& \mathrm{DA}=\alpha+\beta_{1} \text { sala } \mathrm{t} 3+\beta_{2} \mathrm{~h} 10+\beta_{3} \text { sala } \_\mathrm{t} 3 \times \mathrm{h} 10 \\
+ & \beta_{4} \mathrm{n} \_\mathrm{d}+\beta_{5} \text { id }+\beta_{6} \mathrm{dua}+\beta_{7} \text { size } \mathrm{a}+\beta_{8} \text { leve }+\varepsilon
\end{aligned}
$$
where:

$\mathrm{DA}=$ discretionary accruals of the firm, as an indicator for earnings management;

sala t $3=$ natural logarithm of the total salary of the top 3 executives

h10 $=$ index of Herfindahl for ownership concentration;

sala $\mathrm{t} 3 \times \mathrm{h} 10=$ the multiplication cross item equaling sala_t 3 multiplied by h10;

$\mathrm{n} \_\mathrm{d}=$ number of the directors.

$\mathrm{id}=$ the proportion of independent directors;

dua $=$ a dummy variable that equals 1 if the CEO is the chairman or a vice chairman of the board of directors, and 0 otherwise;

size_a $=$ logarithm of the total assets;

leve $=$ Debt ratio calculated by dividing liabilities by assets

After the regression equation has been properly constructed, the next step is to find a way to measure the discretionary accruals (DA). Jones[15] suggested that earnings management can be achieved by various means such as the use of accruals, changes in accounting methods, and changes in capital structure (e.g., debt defeasance, debt-equity swaps). This study focuses on total accruals (TA) as the source of earnings management. Total accruals (TA) include discretionary accruals (DA) and non-discretionary accruals (NDA). Discretionary accruals (DA) are used to measure the level of earnings management of a firm, and are calculated as follows:

$$
\begin{gathered}
\mathrm{TA}_{\mathrm{it}}=\alpha_{1}\left(1 / \mathrm{A}_{\mathrm{it}-1}\right)+ \\
\mathrm{NDA}_{\mathrm{it}}=\alpha_{1}\left(1 / \mathrm{REV}_{\mathrm{it}} / \mathrm{A}_{\mathrm{it}-1}\right)+\alpha_{3}\left(\mathrm{PPE}_{\mathrm{it}} / \mathrm{A}_{\mathrm{it}-1}\right)+\alpha_{2}\left(\Delta \mathrm{REV}_{\mathrm{it}}-\Delta \mathrm{REC}_{\mathrm{it}}\right) / \mathrm{A}_{\mathrm{it}-1} \\
+\alpha_{3}\left(\mathrm{PPE}_{\mathrm{it}} / \mathrm{A}_{\mathrm{it}-1}\right) \\
\mathrm{DA}_{\mathrm{it}}=\mathrm{TA}_{\mathrm{it}}-\mathrm{NDA}_{\mathrm{it}}
\end{gathered}
$$

where:

$\mathrm{DA}_{\mathrm{it}}=$ dealing accruals in year $\mathrm{t}$ for firm $\mathrm{i}$;

$\mathrm{NDA}_{\mathrm{it}}=$ non-dealing accruals in year $\mathrm{t}$ for firm $\mathrm{i}$;

$\mathrm{TA}_{\mathrm{it}}=$ total accruals in year $\mathrm{t}$ for firm $\mathrm{i}$;

$\triangle \mathrm{REV}_{\mathrm{it}}=$ revenues in year $\mathrm{t}$ less revenues in year $1-\mathrm{t}$ for firm i;

$\triangle \mathrm{REC}_{\mathrm{it}}=$ accounts receivables in year $\mathrm{t}$ less accounts receivables in year $\mathrm{t}-1$ for firm $\mathrm{i}$;

$\mathrm{PPE}_{\mathrm{it}}=$ gross property, plant, and equipment in year $\mathrm{t}$ for firm i;

$\mathrm{A}_{\mathrm{it}}=$ total assets in year $\mathrm{t}-1$ for firm $\mathrm{i}$;

$\varepsilon_{\text {it }}=$ error term in year $\mathrm{t}$ for firm $\mathrm{i}$

\section{Data and Descriptive Statistics}

\subsection{Data Collection}

We conduct our analysis with the full set of non-financial companies which were continuously listed on the Shanghai Stock Exchange (SHSE) and the Shenzhen Stock Exchange (SZSE) from 2006 to 2008 period. In these three years, there are both top performance and bottom influence in China's stock market as a emerging market of China. And this time period provides more recent data and at the same time avoids duplication of time spans with previous studies.

Based on above criteria, we extract 1024 SHSE and SZSE listed firms each year and total 2048 firms for our analyses. We use RESSET and CSMAR data sources to collect the data required. These databases are used to collect the corporate governance data and the accounting data. 


\subsection{Summary Statistics}

Table 1 provides some summary statistics for the above variables. As revealed, these 1024 companies have an average dealing accruals (DA) of -0.0259 . The mean of logarithm of total executives' compensation is 13.68. And the average of h10 is 0.1688 .

The number of board is from 5 to 19 , the average is 9.31, which is very fit for the regulation of the Chinese Corporation Law. The mean of the proportion of independent directors is $35.9 \%$, which is satisfied not less than " $1 / 3$ " in the regulation of the Chinese Corporation Law. And the mean of the duality of CEO is 0.1270 , which reflects CEO is mostly not the chairman of the board in most companies.

Finally, in the controlling variables, the mean of scale of assets (size_a) is 21.65, and debt ratio (leve) is $49.97 \%$.

\subsection{Related Coefficient Validity Test}

Table 2 use Pearson related coefficient validity test and Spearman related coefficient validity test to test the selfrelation among the independent variables. The Bottom Left lists the coefficient of Pearson method and the upper right lists the coefficient of Spearman method. Both two methods have showed the acceptable validity test results in Table 2.

\subsection{Regression Models}

In this section, we carry out our econometric analysis. We investigate the effects of the corporate governance mechanisms on earnings management. This study gives us some ideas about the magnitude of the corporate governance premiums which are used to measure the level of corporate governance and earnings management.

Table 3 reports regression results of earnings management variables on the five variables used to measure some of the governance mechanisms and earnings management for China's listed companies. The regression model is regressed by debt ratio and the size of assets as two control variables. Three interesting findings are listed in order.

First, the executive compensation has a positive relationship with earnings management and the coefficient is statistically significant at $1 \%$ level in each model. This result is on the opposite side of the hypothesis 1 .

Second, the ownership concentration is positive significantly in model 3 and 4 while not significantly in model 2, which is different with the hypothesis 2 . Thus, as added in a multiplication cross item of executive compensation and ownership concentration, the coefficient of the multiplication cross item is negative and adverse to the sign of the coefficient of executive compensation. And it is statistically significant at $1 \%$ level, same as the hypothesis 3 . This data result represents the constraint function of ownership concentration to executive compensation on the level of earnings management.

Third, the board variables, such as number of the directors, proportion of independent directors, CEO duality,

Table 1. Descriptive statistics of dependent and independent variables.

\begin{tabular}{ccccc}
\hline Variable & Mean & SD & Min & Max \\
\hline DA & -0.0259 & 0.1384 & -0.7352 & 3.0349 \\
sala_t3 & 13.6823 & 0.7865 & 11.1419 & 21.4206 \\
h10 & 0.1688 & 0.1192 & 0.0023 & 0.7264 \\
sala_t3 $\times$ h10 & 2.3068 & 1.6491 & 0.0310 & 10.5430 \\
dua & 0.1270 & 0.3331 & 0 & 1 \\
n_d & 9.3081 & 1.9482 & 1 & 18 \\
id & 0.3588 & 0.0500 & 0 & 0.6 \\
size_a & 21.6531 & 1.0932 & 18.8266 & 27.3463 \\
leve & 0.4997 & 0.1761 & 0.0182 & 0.9669 \\
\hline
\end{tabular}

Table 2. Pearson and spearman correlation matrix.

\begin{tabular}{|c|c|c|c|c|c|c|c|c|}
\hline & DA & sala_d3 & h10 & dua & n_d & id & size_a & leve \\
\hline DA & 1.0000 & 0.1934 & 0.0805 & -0.0138 & 0.0281 & 0.0316 & 0.3336 & 0.2454 \\
\hline sala_t3 & 0.1559 & 1.0000 & 0.0449 & -0.0143 & 0.1613 & 0.0147 & 0.4086 & 0.2892 \\
\hline h10 & 0.0446 & 0.0397 & 1.0000 & -0.0525 & -0.0068 & -0.0182 & 0.1835 & 0.1621 \\
\hline dua & -0.0070 & -0.0211 & -0.0615 & 1.0000 & -0.1086 & 0.0628 & -0.0903 & 0.0069 \\
\hline $\mathrm{n} \_\mathrm{d}$ & 0.0149 & 0.1628 & -0.0103 & -0.1017 & 1.0000 & -0.1819 & 0.2258 & 0.0182 \\
\hline id & 0.0331 & -0.0046 & 0.0041 & 0.0598 & -0.1978 & 1.0000 & 0.0351 & -0.0337 \\
\hline size_a & 0.1981 & 0.3898 & 0.2520 & -0.0972 & 0.2544 & 0.0186 & 1.0000 & 0.1317 \\
\hline leve & 0.2842 & 0.1513 & 0.1021 & -0.0002 & -0.0223 & -0.0001 & 0.0557 & 1.0000 \\
\hline
\end{tabular}

Notes: the Pearson related coefficients are listed on the bottom left and the Spearman related coefficients are listed on the upper right. 
Table 3. Regression results on earnings management for each model.

\begin{tabular}{|c|c|c|c|c|c|c|c|c|c|}
\hline \multirow[b]{2}{*}{ variable } & \multirow[b]{2}{*}{ pred. sign } & \multicolumn{2}{|c|}{ Model 1} & \multicolumn{2}{|c|}{ Model 2} & \multicolumn{2}{|c|}{ Model 3} & \multicolumn{2}{|c|}{ Model 4} \\
\hline & & coef. & t_value & coef. & t_value & coef. & t_value & coef. & t_value \\
\hline sala_t3 & - & 0.0150 & $3.62^{* * *}$ & & & 0.0322 & $4.83^{* * *}$ & 0.0315 & $4.59^{* * *}$ \\
\hline h10 & - & & & -0.0140 & -0.54 & 1.4170 & $3.29^{* * *}$ & 1.3327 & $2.98^{* * *}$ \\
\hline her_sa & - & & & & & -0.1035 & $-3.31^{* * *}$ & -0.0979 & $-3.02^{* * *}$ \\
\hline id & - & & & & & & & 0.0401 & 0.64 \\
\hline n_d & - & & & & & & & -0.0024 & -1.43 \\
\hline dua & + & & & & & & & 0.0012 & 0.13 \\
\hline size_a & & 0.0247 & $7.9^{* * *}$ & 0.0294 & $9.9^{* * *}$ & 0.0255 & $7.83^{* * *}$ & 0.0267 & $7.85^{* * *}$ \\
\hline leve & & -0.0789 & $-4.43^{* * *}$ & -0.0835 & $-4.69^{* * *}$ & -0.0798 & $-4.47^{* * *}$ & -0.0772 & $-4.20^{* * *}$ \\
\hline _cons & & -0.7278 & $-10.77^{* * *}$ & -0.6180 & $-10.11^{* * *}$ & -0.9779 & $-9.64^{* * *}$ & -0.9866 & $-9.38^{* * *}$ \\
\hline F-value & & & 40.05 & & 35.28 & & 26.33 & & 16.10 \\
\hline $\mathrm{R} 2$ & & & 0.056 & & 0.049 & & 0.061 & & 0.062 \\
\hline Adj-R2 & & & 0.055 & & 0.048 & & 0.059 & & 0.059 \\
\hline
\end{tabular}

do not show statistically significant with earnings management in model 4 . The hypothesis 4,5 and 6 are not passed the empirical test.

Among the two control variables, size_a and leve, are positive and negative significant relationship with earnings management at $1 \%$ level.

\section{Sensitivity Test}

From the above analysis, we find that the ownership concentration has a significant constrain on compensation contract for earnings management. That is, the stronger compensation motivation is, the higher level earning management presents. With the constrain of the ownership concentration, compensation contract shows a indistinctively effect on the earning management.

For the sensitivity test, we use some alternative variables to see for the same sample data and same model if we can get the same empirical results as the above. First, for the executive compensation, we change the top 3 salary of chairman of board of directors or supervisors or CEO to only top 3 managers, and only top3 board of directors. Thus, we use these two variables to alternate sala $\mathrm{t} 3$, and we get the almost the same empirical results.

Second, we change the alternative variable for ownership concentration from the top 10 stockholders (h10) to the top 5 stockholders (h5). And the same significant result and multiplication cross function show the constrain function of ownership concentration for executive compensation.

Then, even for the further proving, we use the sensitivity test-robust test in Stata 10.0-to make if it still show the same results as it illustrates as follows in Table 4.

\section{Conclusions and Suggestion}

This paper empirically studies the impacts of executive compensation on earnings management and its constrain by ownership. We find that some estimated effects of the variables are consistent with theoretical predictions. In particular, executive compensation has statistically significant and positive effects on dealing accruals. This emphasizes that the compensation contract is one of motivation of earnings management. The managers have strong willing to make earnings management to improve their compensation. While we still find that ownership concentration could constrain the effects of compensation motivations on earnings management. It is ownership concentration that constrains the compensation motivation on earnings management.

However, the corporate governance mechanisms, such

Table 4. Robust test for the regression models.

\begin{tabular}{ccccc}
\hline & \multicolumn{2}{c}{ Model 3 } & \multicolumn{2}{c}{ Model 4 } \\
\hline variable & coef. & t_value & coef. & t_value \\
sala_t3 & 0.0071582 & $1.73^{*}$ & 0.0076395 & $1.72^{*}$ \\
h10 & 0.6354436 & $2.40^{* * *}$ & 0.5520881 & $1.92^{* *}$ \\
sala_t3 $\times$ h10 & -0.0471493 & $-2.45^{* * *}$ & -0.0417336 & $-2.00^{* *}$ \\
dua & & & 0.0016183 & 0.27 \\
n_d & & & -0.0027086 & $-2.52^{* * *}$ \\
id & & & 0.0267686 & 0.66 \\
size_a & 0.023105 & $12.24^{* * *}$ & 0.0251899 & $12.16^{* * *}$ \\
leve & 0.485133 & $21.04^{* * *}$ & 0.4744188 & $19.36^{* * *}$ \\
cons & & & -0.6800912 & -10.07 \\
\hline
\end{tabular}


as the board, do not affect the compensation motivation on earnings management. And the board size, board independence and the CEO duality do not present significantly effect on earnings management, which shows the weakness of corporate governance in China's listed firms. The reason why board's function is so weak may be for the current situation and background of China's stock market. Recently, in most listed firms, the board governance is still not so effectively and the independence of the board is not so significant, which weaken the board's influence on earnings management. The board governance regulation and system need to improve, not just on paper, but on real practice. Thus, as a emerging market, the Shanghai Securities Exchange named year 2009 is "the corporate governance year for China's listed firms", which enhance more effective measures on corporate governance, especially board governance.

Our findings have valuable implications for both the security regulators and listed companies in the emerging market of China. It is known that many security regulators in the world, including both the developed and developing countries, have recognized the serious problems of earnings management. They have proposed various ways, known as the best practice codes, to reduce earnings management and improve a firm's overall governance standard. It is our belief that our study sheds light on the relative importance of various corporate governance practices about earnings management, and should provide useful information for Chinese regulatory authorities to design the best practice codes tailored to the Chinese institutional background and current level of emerging market development. In addition, it also provide useful guide for firms to design their corporate governance mechanisms so that they can decrease earnings management, and enhance their corporate governance and improve the Chinese emerging market to develop healthily, stably and harmoniously.

\section{Acknowledgements}

We are grateful to many members of the 2nd Financial Risk \& Corporate Finance Conference in Dalian University of Technology and the 8th International Conference on Supply Chain Management and Information Systems in Hong Kong Polytechnic University. Both authors acknowledge financial support from National Natural Science Foundation of China (71172136) and the Fundamental Research Funds for the Central Universities (DUT10ZD107, DC10040208) and New Century Excellent Talents in University (NCET -10-0281). We are responsible for all remaining errors.

\section{REFERENCES}

[1] D. Hwang, B. Staley, Y. T. Chen, J.-S. Lan, "Confucian Culture and Whistle-Blowing by Professional Accountants: An Exploratory Study," Managerial Auditing Journal, Vol. 23, No. 5, 2008, pp.504-526.

[2] J. A. Berle and G. C. Means. "The Modern Corporation and Private Property," Macmillan, New York, 1932.

[3] E. F. Fama, "Agency Problems and the Theory of the Fine," Journal of Political Economy, Vol. 88, No. 2, 1980, pp. 188-307. doi:10.1086/260866

[4] M. C. Jensen and W. H. Meckling, "Theory of the Firm: Managerial Behavior, Agency Cost and Ownership Structure," Journal of Financial Economics, Vol. 3, No. 4 , 1976, pp. 305-360. doi:10.1016/0304-405X(76)90026-X

[5] R. La Porta, F. Lopez-de-Silanes and A. Shleifer, "Corporate Ownership around the World," Journal of Finance, Vol. 54, No. 2, 1999, pp471-517.

[6] S. Claessens, S. Djankov and L. Lang, "The Separation of Ownership and Control in East Asian Corporations," Journal of Financial Economics, Vol. 58, No. 1-2, 2000, pp. 81-112. doi:10.1016/S0304-405X(00)00067-2

[7] P. M. Healy, "The Effect of Bonus Schemes on Accounting Decisions," Journal of Accounting and Economics, Vol. 7, No. 1-3, 1985, pp. 85-107. doi:10.1016/0165-4101(85)90029-1

[8] R. Watts and J. L. Zimmerman, "Positive Accounting Theory," 1st Edition, Prentice-Hall, Upper Saddle River, 1986.

[9] D. K. Denis and J. J. McConnell, "International Corporate Governance," Journal of Financial and Analysis, Vol. 38, No. 1, 2003, pp. 1-36. doi:10.2307/4126762

[10] P. M. Dechow and P. G. Sloan, "Executive Incentives and the Horizon Problem: An Empirical Investigation," Journal of Accounting and Economics, Vol. 14, No. 1, 1991, pp. 51-89. doi:10.1016/0167-7187(91)90058-S

[11] J. Long, Y.-X. Li and L.-L. Fu, "Is It Governance or Ownership That Affect the Motivation of Compensation Contract on Earnings Management? An Empirical Study on Chinese Listed Firms," 8th International Conference on Supply Chain Management and Information Systems, Hong Kong, 6-9 October 2010, pp. 1-5.

[12] M. Beasley, "An Empirical Analysis of the Relationship between Board of Director Composition and Financial Statement Fraud," The Accounting Review, Vol. 71, No. 4, 1996, pp. 443-465.

[13] P. M. Dechow, R. G. Sloan and A. P. Sweeney. "Detecting Earnings Management," The Accounting Review, Vol. 70, No. 2, 1995, pp. 193-225.

[14] C.-E. Bai, Q. Liu, J. Lu, F. M. Song and J.-X. Zhang, "Corporate Governance and Market Valuation in China," Working Paper, 2004.

[15] J. Jones, "Earnigs Management during Import Relief Investigations," Journal of Accounting Research, Vol. 29, No. 2, 1991, pp. 193-228. 